LPS and MTP-PE (liposome-encapsulated $N$-acetylm u ram yl-L-alan yl-D-is oglu ta m in yl-L-alan in e-2-: [1' , 2' dipalm itoyl-s ni-glycero-3-(hydroxy-phosphoryl-oxyl)] etylamide) induce in liver macrophages a synthesis and release of TNF- $\alpha$, nitric oxide and prostanoids. Both agents induce an expression of mRNA's encoding TNF- $\alpha$, in ducible nitric ox ide synthase (iNOS) and cyclooxygenase (COX)-2, and of corresponding protein s. LPS and MTP-PE induce a rapid activation of the extracellular regulated kinase (ERK) isoenzymes-1 and -2 . In hibition of $m$ ap kinase isoenzymes leads to a decreased release of TNF- $\alpha$, nitric oxide and prostaglandin (PG) $E_{2}$ after both agents. The transcription factors NF- $\kappa B$ and AP-1 are strongly activated by LPS within $30 \mathrm{~m}$ in utes. MTP-PE induces a weak activation of both transcription factors only after 5 hours. Inhibition of NF- $\kappa B$ inhibits the LPS- but not the MTPPE-induced release of TNF- $\alpha$, nitric oxide and $P E_{2}$. PGE $_{2}$ release after LPS is higher than after MTP-PE. Exogenously added $\mathrm{PGE}_{2}$ inhibits the activation of map kinase and TNF- $\alpha$ release by LPS, but not by MTPPE. Release of nitric oxide after LPS and MTP-PE is enhanced after prior addition of $\mathrm{PGE}_{2} . \mathrm{PGD}_{2}$ is without any effect. MTP-PE, but not LPS, induces a cy totoxicity of Kupffer cells again st P815 tum or target cells. The MTP-PE-induced cytotoxicity is reduced by TNF- $\alpha$ neutralizing antibodies, indicating the involvement of TNF- $\alpha$. Thus our results suggest that the different potencies of LPS and MTP-PE as im munomodulators probably result from different actions on Kupffer cells, resulting in differences in the amounts and kinetics of released TNF- $\alpha$ and $\mathrm{PGE}_{2}$, and that $\mathrm{PGE}_{2}$ plays an important regulatory role in the action of LPS, but not in the actions of MTP-PE.

Key words: LPS, Macrophages, Muramyl tripeptides, Cytokines, Eicosanoids

\section{Prostaglandin E2 affects differently the release of inflammatory mediators from resident macrophages by LPS and muramyl tripeptides}

\author{
Peter Dieter ${ }^{1, C A}$, Ute Hempel' ${ }^{1}$ Sabine Kamionka1, \\ Angelika Kolada ${ }^{1}$, Birgit Malessa ${ }^{1}$, Edith Fitzke $^{2}$ and \\ Thuy-Anh Tran-Thi ${ }^{2}$
}

${ }^{1}$ Institute of Physiological Chemistry, Medical Faculty, Dresden University of Technology, Dresden, Germany; ${ }^{2}$ Institute of Biochemistry and Molecular Biology, Albert-Ludwigs-University, Freiburg, Germany
${ }^{\mathrm{CA}}$ Corresponding Author
Institute of Physiological Chemistry, Medical Faculty, Dresden University of Technology, Karl-Marx-Strasse 3, D-01109 Dresden, Germany
Tel: (351) 8832851

Fax: (351) 8832869

Email: dieter@rcs.urz.tu-dresden.de

\section{Introduction}

Liver macrophages (Kupffer cells) are macrophages residing in the sinusoids of the liver. This strategic location makes them the first macrophages to come into contact with noxious materials that enter circulation via the portal vein. This location and the fact that they constitute the largest pool of macrophages in the body attributes to them an important function in the clearance of noxious material, the removal of migrating tumor cells, and in the pathophysiology of septic shock. ${ }^{1}$

Liver macrophages have been reported to secrete a wide array of biologically active compounds including cytokines, prostanoids, nitric oxide and oxygen radicals, which have been shown to be involved in the pathogenesis of septic shock, and in the cytotoxicity of Kupffer cells against tumor target cells. ${ }^{1-7}$

LPS and muramyl tripeptides are components of the outer cell membrane of most bacteria and display most of the immunological activities compared with an infection of whole bacteria. ${ }^{8-11}$ When administrated i.v., LPS and liposome-encapsulated $N$-ace tyl-muramylL-alanyl-D-isoglutaminyl-L-alanine-2-[1', 2' dipalmitoylsn-glycero-3' -(hydroxy-phosphoryl-oxyl)] e thyl-amide (MTP-PE) $^{3}$ are delivered predominantly to macrophages, especially liver macrophages. ${ }^{12,13}$ While LPS has been shown to play a significant role in the pathogenesis of gram-negative septic shock, muramyl tripeptides have been demonstrated to be protective against LPS-induced septicemia. ${ }^{14,15}$ Furthermore, i.v. administered MTP-PE has been shown to induce antitumor reactivity, probably as a result of macrophage activation, ${ }^{16-19}$ and to inhibit HIV replication in macrophages. ${ }^{20}$

In contrast to LPS, very little is known about the intracellular signal transduction pathways of muramyl tripeptides. Recently, we showed that MTP-PE and LPS induce similar reactions in liver macrophages, like the formation of TNF- $\alpha$, nitric oxide and prostanoids. ${ }^{21}$ 
Furthermore, we demonstrated, that cellular calcium and protein kinase $\mathrm{C}$ isoenzymes are not involved in the signal pathw ays of LPS and MTP-PE. ${ }^{21}$

\section{Materials and methods}

\section{Materials}

Medium RPMI 1640, new born and fetal calf serum are purchased from Biochrom (Berlin, Germany); newborn calf serum is heat-inactivated at $56^{\circ} \mathrm{C}$ for $30 \mathrm{~min}$ $\left[\gamma_{-}-{ }^{32} \mathrm{ATP}\right]$ and $\left[{ }^{3} \mathrm{H}\right]$ thymidine are from Amersham Buchler (Braunschweig, Germany). P815 mouse mastocytoma and mouse L929 cells are purchased from American Type Culture Collection (Rockville, USA). Murine rTNF- $\alpha$ and rat TNF- $\alpha$-ne utralizing antibodies are from Boehringer Mannheim (Mannheim, Germany) and IC Chemikalien (Ismaning, Germany), respectively. BAY 11-7082 and PD 98059 are purchased from Calbiochem (Bad Soden, Germany). Monoclonal antibodies against COX-2 and iNOS are purchased from Natutuec (Frankfurt, Germany) and Transduction Laboratories/Dianova (Hamburg, Germany), respectively. MTP-PE is kindly provided by Ciba-Geigy (Basel, Switzerland). LPS R595 from Salmonella minnesota is a gift from Dr Galanos (Freiburg, Germany). Antibodies raised against prostaglandin (PG) $E_{2}$ and $\mathrm{PGD}_{2}$ are generous gifts from $\mathrm{Dr}$ Brune (Erlangen, Germany) and Dr Hayaishi (Osaka, Japan), respectively. RT-PCR reagents and enzymes are from Perkin Elmer (Weiterstadt, Germany). Specific primers (HPLC purified) are synthesized and purchased from Birsner \& Grob (Denzlingen, Germany).

\section{Cell culture}

Livers of male Wistar rats (Charles River, Sulzfeld, Germany) are removed aseptically under Nembutal anaesthesia, and the liver macrophages are isolated by a centrifugal elutriation procedure. ${ }^{22}$ Liver macrophages are maintained in primary culture with RPMI 1640 medium containing $30 \%$ new born calf serum. All experiments are performed with cells kept in primary culture for 48-72 h. P815 mouse mastocytoma cells and L929 cells are grown in RPMI 1640 medium containing $10 \%$ FCS.

\section{Determination of $\mathrm{PGE}_{2}$ and $\mathrm{PGD}_{2}$}

Macrophages are incubated in RPMI medium containing $10 \%$ newborn calf serum with or without LPS or MTP-PE, and after the indicated times cell media are removed and centrifuged. The amount of $\mathrm{PGE}_{2}$ and $\mathrm{PGD}_{2}$ in cell media is measured by ELISA and RIA, respectively, as described elsewhere. ${ }^{23}$

\section{Determination of TNF- $\alpha$ activity}

The release of TNF- $\alpha$ activity is measured using the L929 cell cytotoxicity assay in which lysis of actinomycin-D-treated L929 cells by TNF- $\alpha$ is measured by crystal violet staining of survival cells in monolayer culture. ${ }^{24}$ L929 cells are grown on 96-well microtest plates to the density of $-4 \times 10^{4}$ cells/well. Culture media to be tested are added to the wells together with actinomycin $(400 \mathrm{ng} / \mathrm{w}$ ell). After $24 \mathrm{~h}$, the supernatants are discharged and the remaining cells are stained with $0.5 \%$ crystal violet in $25 \%$ aqueous methanol for $10 \mathrm{~min}$. The dye is removed by washing three times with $25 \%$ methanol, and 5\% SDS is added to solubilize the adherent cells. Then the aborbance is read with a microplate reader (Titertek Multiskan Plus) at $550 \mathrm{~nm}$. The absorbance is compared with that of a standard solution of murine rTNF- $\alpha$. Units of TNF- $\alpha$ activity are the reciprocal dilution factor of a sample causing $50 \%$ lysis of L929 cells. The specificity is controlled by neutralization with rat TNF- $\alpha$-neutralizing antibodies (dilution of 1:50).

\section{Determination of nitric oxide}

Macrophages are incubated in RPMI medium containing $10 \%$ newborn calf serum with or without LPS or MTP-PE, and after the indicated times cell media are removed and centrifuged. Nitric oxide formation is measured as $\mathrm{NO}_{2}{ }^{-}$accumulated in the cell media, which reflects the release of nitric oxide from macrophages. ${ }^{3}$ The Griess reaction using $20 \mu \mathrm{l}$ of sulfanilamide $(10 \mathrm{mM}), 10 \mu \mathrm{l}$ of $\mathrm{HCl}(2 \mathrm{M}), 10 \mu \mathrm{l}$ of naphtyle thyle nediamine dihydrochloride $(1 \mathrm{mM})$, and $150 \mu \mathrm{l}$ of supernatant is applied to each well of a microtiter plate; the pink azo dye is quantitated by a microplate reader (Titertek Multiskan Plus) at $550 \mathrm{~nm}$. Standards are prepared using $\mathrm{NaNO}_{2}{ }^{-}$.

\section{In vitro cytotoxicity assay}

Macrophages are cultured on 96-well plates at a density of $-10^{5}$ cells/well. P815 target cells in the exponential growth phase are radiolabeled by a 24 h-incubation in RPMI medium with $10 \%$ FCS containing $20 \mu \mathrm{Ci}$ of $\left[{ }^{3} \mathrm{H}\right]$ thymidine $/ 10^{6}$ cells in $5 \mathrm{ml}$. Then the cells are washed three times to remove the radioisotope and resuspended in culture medium to a concentration of $10^{5}$ cells $/ \mathrm{ml} .100 \mu \mathrm{l}\left(10^{4}\left[{ }^{3} \mathrm{H}\right]\right.$ thymidine-labeled target cells) is added to cultured macrophages in a total volume of $200 \mu \mathrm{lof}$ medium/well. LPS or MTP-PE is added to macrophages $6 \mathrm{~h}$ before the addition of target cells. Radiolabeled target cells are also plated alone as an additional control. $48 \mathrm{~h}$ after the addition of target cells, the supernatants are collected and the radioactivity is measured in a liquid scintillation counter. Cytolysis is calculated as follows: $\%$ cytolysis $=100 \times(a-b) /(c-b)$, where $a=\mathrm{cpm}$ in 
supernatants of target cells cocultured with macrophages, $b=\mathrm{cpm}$ in supernatants of target cells cultured alone, $c=\mathrm{cpm}$ in the total amount of target cells added per well.

\section{Western blot analysis}

Total protein $(10 \mu \mathrm{g})$ is separated on $10 \%$ polyacrylamide gels under reducing conditions. Proteins are transferred to nitrocellulose membranes, and nonspecific binding is blocked by incubation in PBS containing $0.1 \%$ Tween 20 and $5 \%$ milk powder. The plots are probed with antibodies against COX-2 and iNOS. After ex tensive washing, the blots are incubated with the secondary antibodies, washed extensively and developed using the ECL Western blotting detection system (Amersham). For quantitative analysis, the bands are scanned densitometrically.

\section{In situ map-kinase assay}

Map kinase activity is performed by an in vitro renaturation assay. ${ }^{25,26}$ Cells are washed with PBS and lysed in $50 \mathrm{mM}$ Tris- $\mathrm{HCl}, \mathrm{pH} 7.5,150 \mathrm{mM} \mathrm{NaCl}, 1 \%$ (w/v) Triton X-100, $0.1 \mathrm{mM} \mathrm{Na}_{3} \mathrm{VO}_{4}, 1 \mathrm{mM}$ phenylmethylsulfonyl fluoride, $0.1 \mathrm{mM}$ aprotinin, vortexed and centrifuged at $15000 \times g$ for $30 \mathrm{~min}$. The supernatants are matched for protein content (BioRad protein dye assay) and diluted to $1 \mathrm{mg} / \mathrm{ml}$ protein in $62.5 \mathrm{mMTris}-\mathrm{HCl}, \mathrm{pH} 6.8$, containing $2.3 \%(\mathrm{w} / \mathrm{v}$ ) SDS, $5 \mathrm{mMEDTA}, 10 \%(\mathrm{v} / \mathrm{v})$ glyce rol and $100 \mathrm{mMDTT}$ and heated at $86^{\circ} \mathrm{C}$ for $5 \mathrm{~min}$ before SDS-PAGE. The gels are polymerized with $0.2 \mathrm{mg} / \mathrm{ml}$ myelin basic protein and, after electrophoresis, denatured in $6 \mathrm{M}$ guanidine hydrochloride. After renaturation, the gels are preincubated in $25 \mathrm{mM}$ HEPES, pH 7.4, $2 \mathrm{mM}$ 2-mercapto ethanol, $10 \mathrm{mM} \mathrm{MgCl}_{2}, 0.1 \mathrm{mM} \mathrm{Na}_{3} \mathrm{VO}_{4}$ and $0.5 \mathrm{mM}$ EGTA at $30^{\circ} \mathrm{C}$ for $30 \mathrm{~min}$. The kinase reaction is performed by incubation of the gels in 25 mM HEPES, $\mathrm{pH}$ 7.4, $2 \mathrm{mM}$ 2-mercaptoethanol, $10 \mathrm{mM} \mathrm{MgCl}_{2}$, $0.1 \mathrm{mM} \mathrm{Na} \mathrm{VO}_{4}, 0.5 \mu \mathrm{M}$ EGTA, $25 \mu \mathrm{M}$ ATP and $250 \mu \mathrm{Ci}\left[\gamma_{-}{ }^{32} \mathrm{P}\right] \mathrm{ATP}$.

\section{Electrophoretic mobility shift assay}

Determination of the DNA-binding capacity of NF-кB and AP-1 is performed exactly as described previously. ${ }^{27}$

\section{RT-PCR studies}

RNA from macrophages is prepared according to Chomzynski and Sacchi. ${ }^{28}$ In brief, $1-2 \times 10^{6}$ macrophages are frozen in liquid nitrogen, taken up in guanidinium thiocyanante and extracted with acidified phenol/chloroform. After centrifugation, RNA is precipitated from the aqueous phase with isopropanol. The pellet is washed once with $80 \%$ ethanol and then taken up in $10 \mu 1 \mathrm{H}_{2} \mathrm{O}$. The total amount of RNA is determined spectrophotometrically and reverse transcribed $\left(22^{\circ} \mathrm{C} / 10 \mathrm{~min}-42^{\circ} \mathrm{C} / 60 \mathrm{~min}-95^{\circ} \mathrm{C} / 5 \mathrm{~min} /\right.$ $4^{\circ} \mathrm{C}$, Perkin Elmer PCR System 2400) using recombinant moloney murine leukemia virus reverse transcriptase $(2.5$ units $/ \mu \mathrm{l})$ in $500 \mathrm{mM} \mathrm{KCl}, 100 \mathrm{mM}$ Tris-HCl, $\mathrm{pH} 8.3,5 \mu \mathrm{M} \mathrm{MgCl}, 2.5 \mu \mathrm{M}$ random hexamers, 1 unit/ $\mu$ RNAse inhibitor, $2.5 \mu \mathrm{M}$ of each dATP, dCTP, dGTP, dTTP and approximately $0.5 \mathrm{mg}$ RNA in a total volume of $10 \mu \mathrm{l}$. For PCR analysis, a master mix is prepared containing buffer $(500 \mathrm{mM}$ $\mathrm{KCl}, 100 \mathrm{mMTris}-\mathrm{HCl}, \mathrm{pH}$ 8.3), $\mathrm{MgCl}_{2}$ (final concentration $1 \mathrm{mM}$ ) and AmpliTaq DNA Polymerase (final concentration 1.25 units $/ 50 \mu \mathrm{l}$ ). For single PCR analysis, $35 \mu \mathrm{l}$ of master mix solution, $5 \mu$ of specific primers and $10 \mu \mathrm{l}$ of reverse-transcribed cellular RNA are added. To compare the levels of mRNA in cells treated for different times without or with LPS or MTP-PE, $\beta$-actin is chosen to standardize the different samples. mRNA levels encoding $\beta$-actin did not change upon treatment of macrophages with LPS or MTP-PE (data not shown). In previous experiments, using different amounts of RNA and different amplification cycles, the amount of RNA for the different PCR reactions was then chosen so that the amount of specific amplified products increased roughly logarithmically between 25 and 35 cycles. Final PCR conditions are as followed (Perkin Elmer PCR System 2400):

$\beta$-actin [1 ng cDNA, $0.5 \mu \mathrm{M}$ primer

\section{(CTCCTTAATGTCACGCACGATTTC/} GTGGGGCGCCCCAGGCACCA),

$94^{\circ} \mathrm{C} / 5 \mathrm{~min}, \quad 52^{\circ} \mathrm{C} \quad 15 \mathrm{~min}-72^{\circ} \mathrm{C} / 2 \mathrm{~min}-94^{\circ} \mathrm{C} / 1 \mathrm{~min}$ (30 cycles) $\left.-52^{\circ} \mathrm{C} / 2 \min -72^{\circ} \mathrm{C} / 10 \min -4^{\circ} \mathrm{C}\right]$;

TNF- $\alpha[100$ ng cDNA, $0.5 \mu \mathrm{M}$ primer

\section{(ATGAGCACAGAAAGCATGATC/ CAGAGCAATGACTCCAAAGTA),}

$94^{\circ} \mathrm{C} / 5 \mathrm{~min}, \quad 52^{\circ} \mathrm{C} / 5 \mathrm{~min}-72^{\circ} \mathrm{C} / 2 \mathrm{~min}-94^{\circ} \mathrm{C} / 1 \mathrm{~min}-$ $52^{\circ} \mathrm{C} / 2 \mathrm{~min}(30$ cycles $)-72^{\circ} \mathrm{C} / 10 \mathrm{~min}-4^{\circ} \mathrm{C}$;

COX-1 [10 ng cDNA, $0.5 \mu \mathrm{M}$ primer

\section{(TGCATGTGGCTGTGGAGTTCATCAA/ CACTAAGACAGACCCGTCTTCTCCA),}

$94^{\circ} \mathrm{C} / 5 \mathrm{~min}, \quad 65^{\circ} \mathrm{C} / 5 \mathrm{~min}-72^{\circ} \mathrm{C} / 2 \mathrm{~min}-94^{\circ} \mathrm{C} / 1 \mathrm{~min}-$ $65^{\circ} \mathrm{C} / 2 \mathrm{~min}(30$ cycles $\left.)-72^{\circ} \mathrm{C} / 10 \mathrm{~min}-4^{\circ} \mathrm{C}\right]$;

COX-2 [100 ng cDNA, $0.5 \mu \mathrm{M}$ primer

\section{(ACTCACTCAGTTTGTTGAGTCATTC/} TTTGATTAGTACTGTAGGGTTAATG),

$94^{\circ} \mathrm{C} / 5 \mathrm{~min}, \quad 55^{\circ} \mathrm{C} / 5 \mathrm{~min}-72^{\circ} \mathrm{C} / 2 \mathrm{~min}-94^{\circ} \mathrm{C} / 1 \mathrm{~min}-$ $55^{\circ} \mathrm{C} / 2 \mathrm{~min}(30$ cycles $\left.)-72^{\circ} \mathrm{C} / 10 \mathrm{~min}-4^{\circ} \mathrm{C}\right]$;

iNOS [100 ng cDNA, 500 ng primer

\section{(GCTTGCCCCTGGAAGTTTCTC/} CCGACCTGATGTTGCCACTGT),

$94^{\circ} \mathrm{C} / 5 \mathrm{~min}, \quad 65^{\circ} \mathrm{C} / 5 \mathrm{~min}-72^{\circ} \mathrm{C} / 2 \mathrm{~min}-94^{\circ} \mathrm{C} / 1 \mathrm{~min}-$ $65^{\circ} \mathrm{C} / 2 \mathrm{~min}$ (30 cycles) $-72^{\circ} \mathrm{C} / 10 \mathrm{~min}-4^{\circ} \mathrm{C}$ ] $10 \mu \mathrm{l}$ of the PCR reaction are loaded onto a $1.5 \%$ agarose gel. The bands ( $\beta$-actin: $610 \mathrm{bp}$, TNF- $\alpha$ : $710 \mathrm{bp}$, COX-2: 


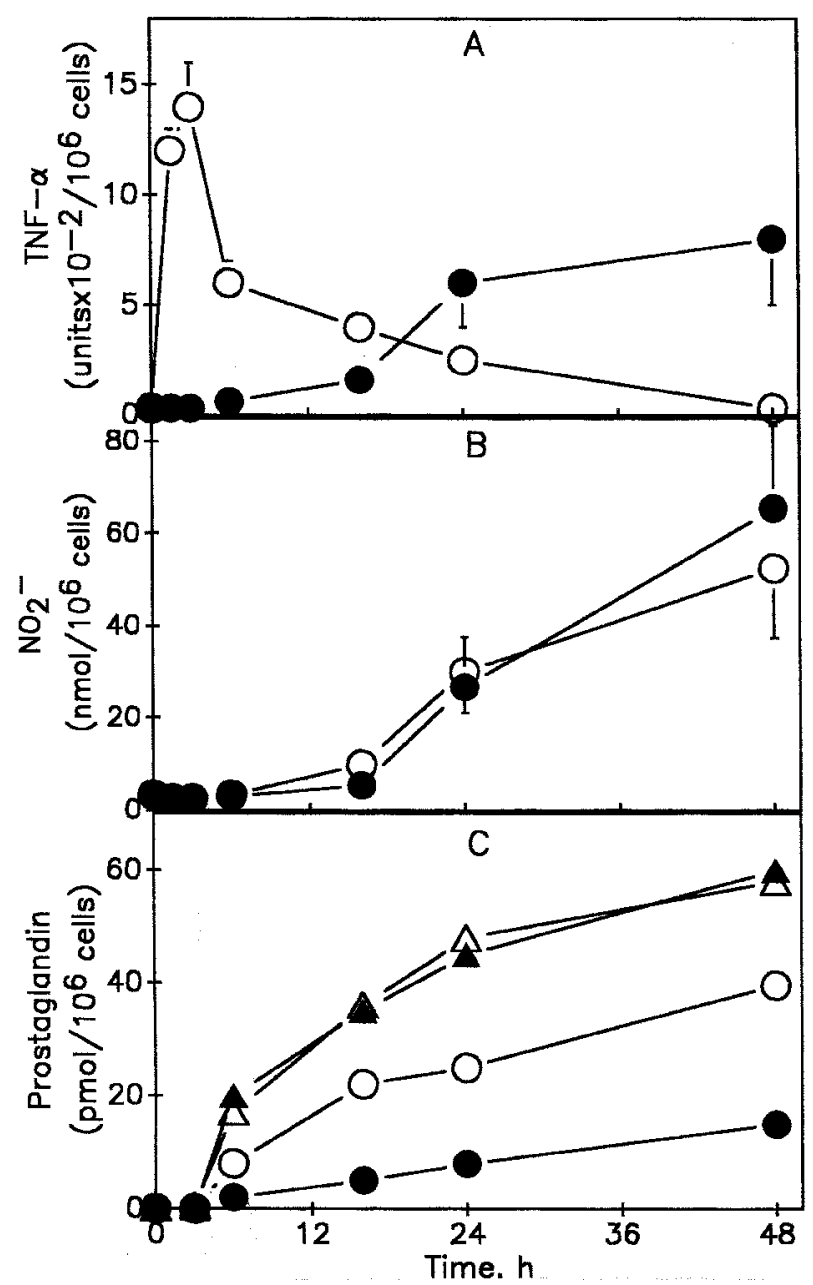

FIG. 1. Effect of LPS and MTP-PE on the release of TNF- $\alpha$, nitric oxide, $P G E_{2}$ and $P G D_{2}$. Macrophages are incubated for the indicated times in RPMI medium containing $10 \%$ newborn calf serum with LPS (open symbols, $500 \mathrm{ng} / \mathrm{ml}$ ) or with MTP-PE (closed symbols, $25 \mu \mathrm{g} / \mathrm{ml}$ ). At indicated time points, accumulation of TNF- $\alpha$ activity (A), nitric oxide (B), $\mathrm{PGE}_{2}(\mathrm{C}$, circles), and $\mathrm{PGD}_{2}$ (C, triangles) in cell media is determined as described in Materials and Methods. Values represent means \pm SD of four experiments.

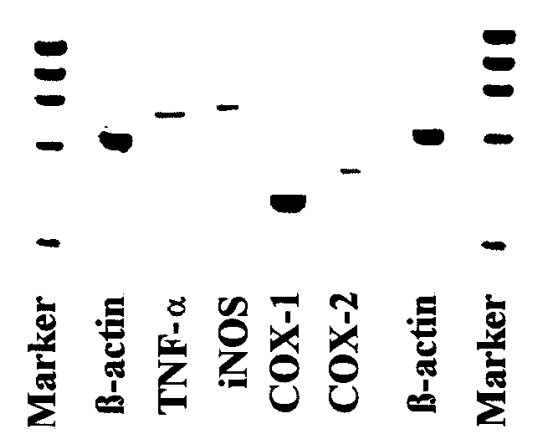

FIG. 2. RT-PCR analysis of mRNA isolated from unstimulated macrophages. Macrophages are cultured for $72 \mathrm{~h}$ in RPMI medium containing $10 \%$ newborn calf serum. RNA is isolated and RT-PCR analysis is performed as described in Materials and Methods. Marker, $\phi$ X174/Hae III $(1353,1078$, $872,603,310 \mathrm{bp})$. A representative set of experiments is shown which is reproduced at least six times.
$583 \mathrm{bp}$, iNOS: $818 \mathrm{bp}$ ) are visualized on a transilluminator after ethidium bromide staining and, for semiquantitative analysis, scanned densitometrically (E.A.S.Y. RH, Herolab, Germany). To compare mRNA expression in cells treated different times with or without LPS or MTP-PE, corresponding mRNA levels are first calculated as expression compared to $\beta$-actin mRNA, the resulting values of control cells are set to 1 and levels of mRNA in LPS- and MTP-PE-treated cells are expressed as 'fold of control cells'.

\section{Results}

Release of TNF- $\alpha$, nitric oxide and prostaglandins

LPS and MTP-PE induce a synthesis and release of TNF- $\alpha$, nitric oxide and prostanoids in macrophages (Fig. 1). LPS induces a rapid and transient accumulation

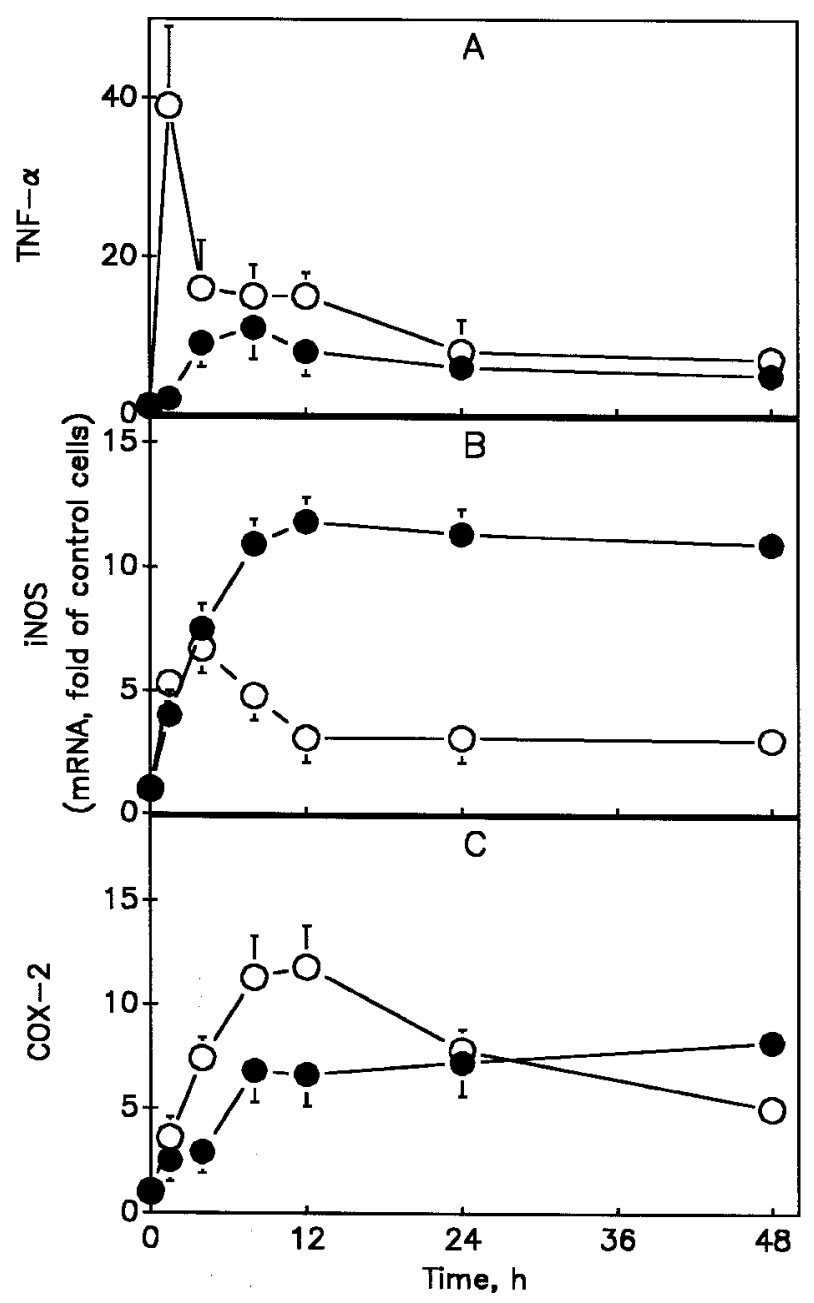

FIG. 3. Effect of LPS and MTP-PE on the accumulation of mRNA encoding TNF- $\alpha$, iNOS and COX-2. Macrophages are incubated for the indicated times in RPMI medium containing $10 \%$ newborn calf serum with LPS (open circles, $500 \mathrm{ng} /$ $\mathrm{ml}$ ) or with MTP-PE (closed circles, $25 \mu \mathrm{g} / \mathrm{ml}$ ). At indicated time points, RNA is isolated and RT-PCR analysis is performed as described in Materials and Methods. Values represent means \pm SD of four experiments. 


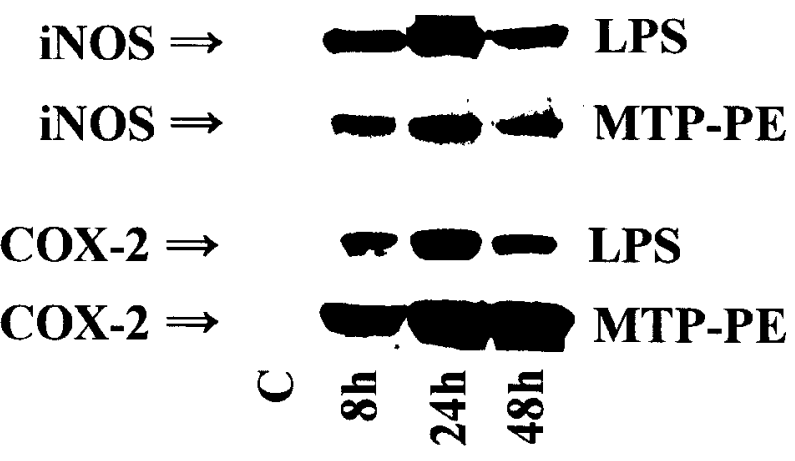

FIG. 4. Western blot analysis of iNOS and COX-2. Macrophages are incubated in RPMI medium containing $10 \%$ newborn calf serum without (C), with LPS $(500 \mathrm{ng} / \mathrm{ml})$ or with MTP-PE $(25 \mu \mathrm{g} / \mathrm{ml})$. At indicated time points, protein is isolated and Western blot analysis is performed as described in Materials and Methods. A representative set of experiments is shown, which is reproduced at least three times.

of TNF- $\alpha$, MTP-PE-induced TNF- $\alpha$ release show s a lag phase of about $6 \mathrm{~h}$, and increases the reafter up to $48 \mathrm{~h}$ (Fig. 1A). The release of nitric oxide (Fig. 1B) and $\mathrm{PGD}_{2}$ (Fig. 1C) is almost identical for both agents. The release of $\mathrm{PGE}_{2}$ after LPS is higher than after MTP-PE (Fig. 1C).

\section{mRNA and protein levels}

In order to investigate at which levels LPS and MTP-PE induce the formation of TNF- $\alpha$, nitric oxide and prostanoids, corresponding mRNA and protein levels are determined by RT-PCR and Western blot analysis, respectively. Figure 2 shows that unstimulated macrophages contain very small amounts of mRNAs encoding TNF- $\alpha$, iNOS and COX-2. mRNAs encoding $\beta$-actin and COX-1 are expressed at much higher levels (Fig. 2). LPS induces a rapid and transient accumulation of TNF- $\alpha$ mRNA with a maximum at about $1.5 \mathrm{~h}$ (Fig. $3 \mathrm{~A})$. In contrast, TNF- $\alpha$ mRNA after MTP-PE becomes detectable only after a lag phase of about $4 \mathrm{~h}$. Both,

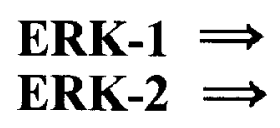

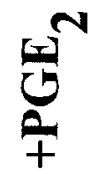
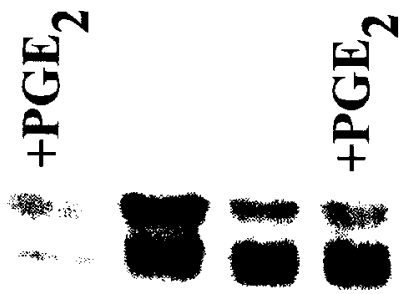

\section{C}

\section{MTP-PE}

FIG. 5. Effect of LPS, MTP-PE and $\mathrm{PGE}_{2}$ on map kinase isoenzymes ERK-1 and ERK-2. Macrophages are incubated in Hanks' solution without or with $\mathrm{PGE}_{2}(1 \mu \mathrm{M})$ as indicated. After $10 \mathrm{~min}$, vehicle (C), LPS $(500 \mathrm{ng} / \mathrm{ml})$ or MTP-PE $(25 \mu \mathrm{g} / \mathrm{ml})$ is added for another $10 \mathrm{~min}$. Thereafter, cells are lysed, subjected to SDS-PAGE, and an 'in gel kinase assay' is performed as described in Materials and Methods. The position of the map kinase isoenzymes ERK-1 and ERK-2 is indicated. A representative set of experiments is shown, which is reproduced at least three times. $\mathrm{PGE}_{2}$ alone is without any effect.
Table 1. Effect of PD 98059 and BAY 11-7082 on the release of TNF- $\alpha$, nitric oxide and $\mathrm{PGE}_{2}{ }^{\mathrm{a}}$

\begin{tabular}{lccc}
\hline Treatment & TNF- $\alpha$ & $\begin{array}{c}\text { Nitric oxide } \\
\text { (\% control cells) }\end{array}$ & PGE $_{2}$ \\
& & & \\
\hline LPS & 100 & 100 & 100 \\
$\quad+$ PD 98059 & $2 \pm 4$ & $28 \pm 9$ & $37 \pm 7$ \\
$\quad+$ BAY 11-7082 & $1 \pm 2$ & $4 \pm 5$ & $40 \pm 11$ \\
MTP-PE & 100 & 100 & 100 \\
$\quad+$ PD 98059 & $1 \pm 2$ & $69 \pm 12$ & $1 \pm 2$ \\
+BAY 11-7082 & $111 \pm 2$ & $128 \pm 29$ & $159 \pm 38$ \\
\hline
\end{tabular}

${ }^{\text {a }}$ Macrophages $(48 \mathrm{~h})$ are incubated in RPMI medium containing $10 \%$ newborn calf serum in the absence or presence of PD $90859(10 \mu \mathrm{M}$, $4 \mathrm{~h})$ or BAY $11-7082(10 \mu \mathrm{M}, 1 \mathrm{~h})$. Thereafter, LPS $(500 \mathrm{ng} / \mathrm{ml})$ or MTP$\mathrm{PE}(25 \mathrm{mg} / \mathrm{ml})$ is added. TNF- $\alpha$ is measured $4 \mathrm{~h}$ after LPS and $24 \mathrm{~h}$ after MTP-PE; $\mathrm{NO}_{2}^{-}$and PGE 2 are measured $24 \mathrm{~h}$ after LPS and MTP-PE in cell media as described in Materials and Methods. Values represent means \pm SD of four to seven experiments.

LPS and MTP-PE induce a rapid accumulation of iNOS mRNA (Fig. 3B). The level of iNOS mRNA after LPS peaks at about $4 \mathrm{~h}$, and declines thereafter. In contrast, MTP-PE induces an increase of iNOS mRNA up to $12 \mathrm{~h}$, which remains thereafter elevated at this level. COX-2 mRNA increases rapidly to similar levels after the addition of LPS and MTP-PE (Fig. 3C). Resting macrophages show no detectable amounts of iNOS and COX-2 protein (Fig. 4). Addition of LPS and MTP$\mathrm{PE}$ induce an expression of both proteins, which becomes detectable at first after 6-8 h. LPS induces a higher expression of iNOS protein $(24 \mathrm{~h})$, COX-2 protein is higher expressed after MTP-PE.

\section{Activation of ERK-1 and -2}

Recently we demonstrated that calcium and protein kinase $\mathrm{C}$ isoenzymes are not involved in the actions of LPS and MTP-PE in macrophages. ${ }^{21}$ Here we show (Fig. 5), that both agents induce a rapid activation of the map kinase isoenzymes extracellular regulated kinase (ERK)-1 and ERK-2.

\section{Activation of NF-kB and AP-1}

LPS induces a rapid activation of the transcription factors NF-kB and AP-1 (Fig. 6). No activation of both transcription factors at this early time-point is seen with MTP-PE. Activation of NF-kB and AP-1 by MTP-PE becomes detectable only after a lag phase of about $5 \mathrm{~h}$, and is weaker pronounced than with LPS.

\section{Effect of inhibitors of ERK-1, -2 and NF- $k B$ on} the release of TNF- $\alpha$, nitric oxide and $\mathrm{PGE}_{2}$

Inhibition of the map kinase isoenzymes ERK-1 and ERK-2 by PD $98059^{29}$ leads to a decreased release of TNF- $\alpha$, nitric oxide and $\mathrm{PGE}_{2}$ (Table 1). TNF- $\alpha$ release after LPS and MTP-PE, and PGE 2 release after MTP-PE is 
$\mathbf{N F - k B} \Longrightarrow$

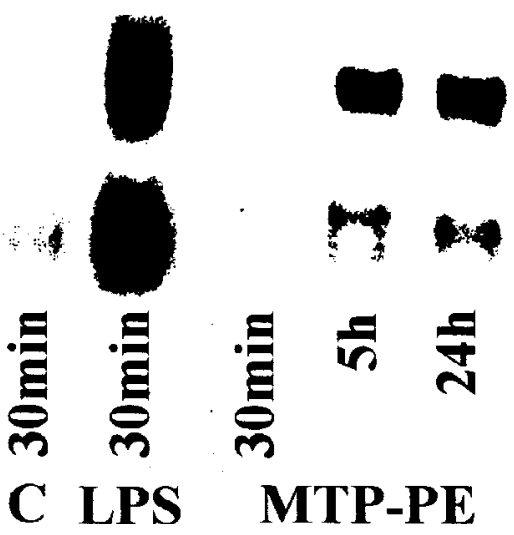

FIG. 6. Activation of NF-kB and AP-1. Macrophages are incubated in Hanks' solution without (C), with LPS (500 ng/ $\mathrm{ml}$ ), or with MTP-PE $(25 \mu \mathrm{g} / \mathrm{ml})$ for the indicated times. Thereafter, cells are extracted and DNA binding activity to $N F-\kappa B$ and AP-1 is monitored in electrophoretic mobility shift assays as described in Materials and Methods. A representative set of experiments is shown, which is reproduced at least three times.

comple tely inhibited by PD 98059. The release of nitric ox ide after LPS and MTP-PE, and of PGE $_{2}$ after MTP-PE, is inhibited by PD 98059 by about $70 \%, 30 \%$ and $60 \%$ respectively (Table 1). Inhibition of the transcription factor NF-kB by BAY $11-7082^{30}$ has no effect on the MTP-PE-induced release of TNF- $\alpha$, nitric oxide and $\mathrm{PGE}_{2}$ (Table 1). How ever, the LPS-induced release of TNF- $\alpha$ and nitric oxide is completely inhibited by BAY 11-7082. The release of $\mathrm{PGE}_{2}$ after LPS is inhibited by BAY $11-7082$ by about $60 \%$ (Table 1 ).

\section{Effect of $P G E_{2}$ and $P G D_{2}$}

$\mathrm{PGE}_{2}$, exogenously added to macrophages, inhibits TNF- $\alpha$ release by LPS but not by MTP-PE (Table 2). In

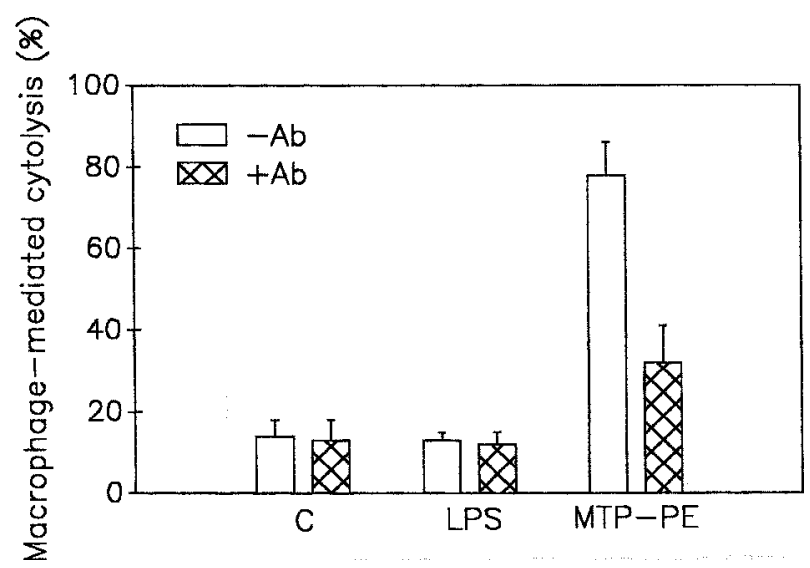

FIG. 7. Effect of LPS and MTP-PE on cytotoxicity of macrophages against P815 tumor target cells. Macrophages (48 h in primary culture) are incubated for $6 \mathrm{~h}$ in RPMI medium containing $10 \%$ newborn calf serum without (C), with LPS $(500 \mathrm{ng} / \mathrm{ml})$ or with MTP-PE $(25 \mu \mathrm{g} / \mathrm{ml})$. Thereafter, P815 target cells, and TNF- $\alpha$ neutralizing antibodies (Ab, $10 \mu \mathrm{l})$, as indicated, are added. $48 \mathrm{~h}$ later, cytolysis is determined as described in Materials and Methods. Values represent means \pm SD of five experiments.
Table 2. Effect of $P G E_{2}$ and $P G D_{2}$ on LPS- and MTP-PEinduced accumulation of TNF- $\alpha$ activity and $\mathrm{NO}_{2}{ }^{-\mathrm{a}}$

\begin{tabular}{ccc}
\hline Treatment & TNF- $\alpha$ activity & Nitric oxide \\
& (Units $\times 10^{-2} / 10^{6}$ cells $)$ & $\left(\mathrm{NO}_{2}{ }^{-}, \mathrm{nmol} / 10^{6}\right.$ cells $)$
\end{tabular}

\begin{tabular}{lrc}
\hline None & n.d. & n.d. \\
LPS & $20 \pm 8$ & $28 \pm 11$ \\
$\quad+$ PGE $_{2}$ & $1 \pm 3$ & $86 \pm 9$ \\
+ PGD $_{2}$ & $22 \pm 6$ & $31 \pm 7$ \\
MTP-PE & $8 \pm 3$ & $26 \pm 7$ \\
+ PGE $_{2}$ & $10 \pm 5$ & $79 \pm 10$ \\
+ PGD $_{2}$ & $7 \pm 4$ & $24 \pm 11$
\end{tabular}

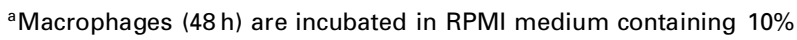
newborn calf serum without (None), with $\mathrm{PGE}_{2}(1 \mu \mathrm{M})$ or with $\mathrm{PGD}_{2}$ $(1 \mu \mathrm{M}) .15 \mathrm{~min}$ later, LPS $(500 \mathrm{ng} / \mathrm{ml})$ or MTP-PE $(25 \mu \mathrm{g} / \mathrm{ml})$ is added. TNF- $\alpha$ is measured $4 \mathrm{~h}$ after LPS and $24 \mathrm{~h}$ after MTP-PE; $\mathrm{NO}_{2}{ }^{-}$is measured $24 \mathrm{~h}$ after LPS and MTP-PE in cell media as described in Materials and Methods. n.d., not detectable. Values represent means \pm SD of four experiments.

contrast, the release of nitric oxide after LPS and MTP$\mathrm{PE}$ is enhanced by prior addition of $\mathrm{PGE}_{2} . \mathrm{PGD}_{2}$ is without any effect (Table 2). In order to investigate at which level $\mathrm{PGE}_{2}$ exerts its action, the effect of exogenously added $\mathrm{PGE}_{2}$ on the activation of map kinase isoenzymes ERK-1 and ERK-2 is determined. $\mathrm{PGE}_{2}$ has no effect on the MTP-PE-induced activation of ERK-1 and ERK-2 (Fig. 6). However, map kinase activation by LPS is completely suppressed.

\section{Effect of LPS and MTP-PE on the cytotoxicity of macrophages}

MTP-PE but not LPS activates macrophages to cytotoxicity against P815 tumor target cells (Fig. 7). Addition of neutralizing antibodies against TNF- $\alpha$ reduced the cyto tox ic effect of MTP-PE by about $75 \%$, indicating that TNF- $\alpha$ is involved in the cytotoxic reaction.

\section{Discussion}

Here we show that LPS and MTP-PE induce a release of TNF- $\alpha$, nitric oxide, $\mathrm{PGE}_{2}$ and $\mathrm{PGD}_{2}$ in macrophages. Both agents increase mRNA's encoding TNF- $\alpha$, iNOS and COX-2 indicating their action at the transcriptional level. We demonstrated recently that macrophages do not express constitutive NOS, ${ }^{31}$ which suggests that the observed release of nitric oxide after LPS and MTP-PE is catalysed by iNOS. The formation of prostanoids after LPS is probably due to the enhanced expression of COX-2 (Fig. 3C) and an enhanced expression of cytosolic phospholipase $\mathrm{A}_{2}{ }^{31}$ Since MTP-PE has no effect on cytosolic phospholipase $A_{2},{ }^{31}$ prostanoid release after MTP-PE seems to be triggered only by the enhanced expression of COX2. We could also demonstrate recently that LPS and 


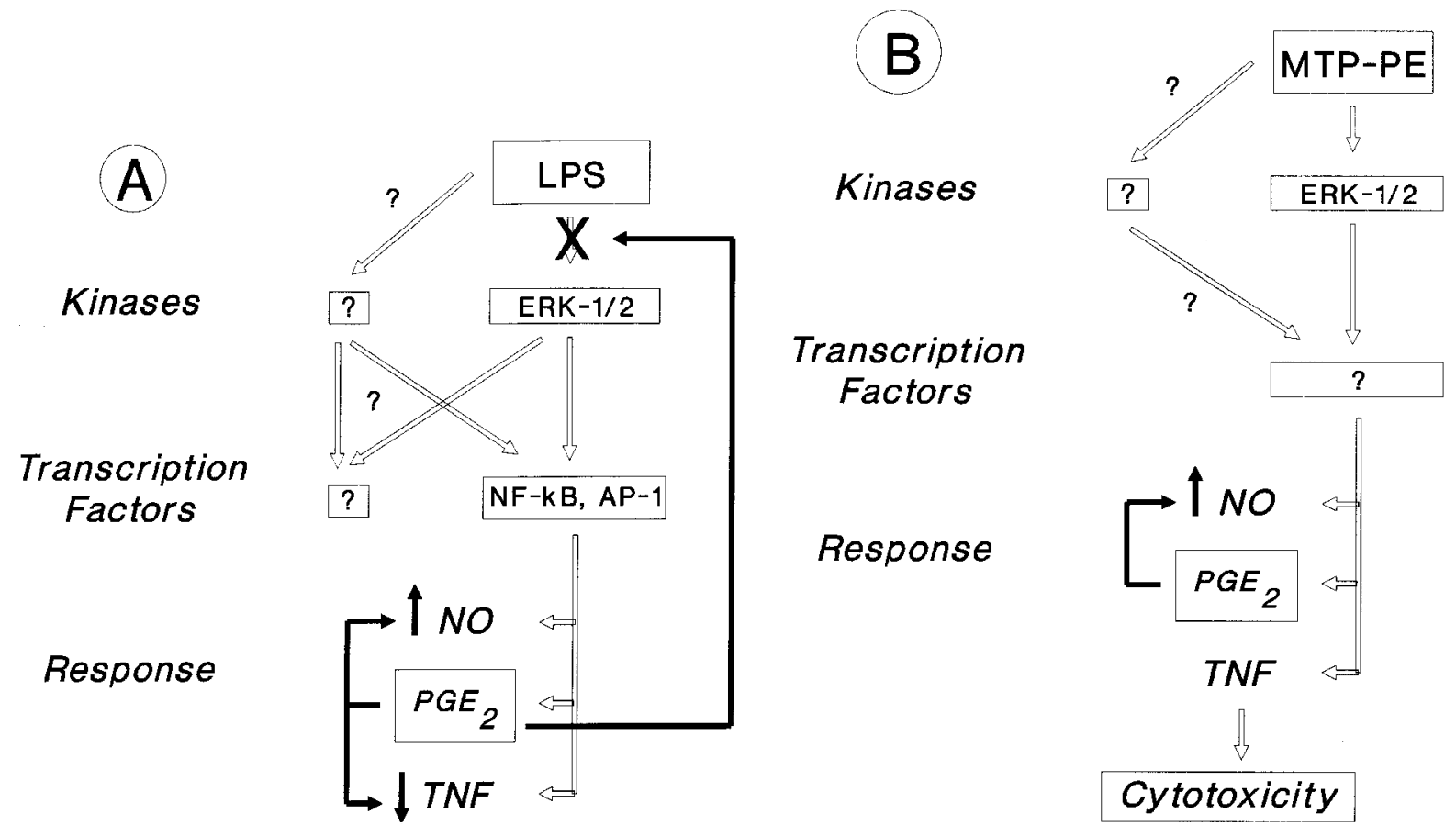

FIG. 8. Tentative scheme for the actions of LPS (A), MTP-PE (B) and $P G E_{2}$ in macrophages.

MTP-PE have no effect on COX-1 levels, and that the constitutive nitric oxide synthase and secretory phosholipase $\mathrm{A}_{2} \mathrm{~s}$ are not expressed in these cells. ${ }^{31}$

While the release of nitric oxide and $\mathrm{PGD}_{2}$ is almost identical for both immunomodulators, the formation of TNF- $\alpha$ and PGE 2 after LPS and MTP-PE is different. (1) Accumulation of TNF- $\alpha$ mRNA and TNF- $\alpha$ activity after LPS is transient, a sustained release of TNF- $\alpha$ is induced by MTP-PE. The finding, that $\mathrm{PGE}_{2}$ inhibits TNF- $\alpha$ release after LPS, but not after MTP-PE (Table 2 ), indicates that the mechanisms underlying TNF- $\alpha$ formation are different for both immunomodulators. It has been shown recently that the inhibition of the LPS-induced TNF- $\alpha$ release by PGE 2 can be mimicked by cAMP, ${ }^{4}$ suggesting that intracellular cAMP mediates the effect of $\mathrm{PGE}_{2}$. (2) $\mathrm{PGE}_{2}$ release after LPS is higher than after MTP-PE. It has been suggested recently that the high $\mathrm{PGE}_{2}$ formation after LPS might be due to an activation of the $\mathrm{PGE}_{2}$ synthase. ${ }^{32,33}$

We demonstrated recently that both immunomodulators do not induce an activation of the 'phosphatidyl inositol cycle', of prote in kinase C isoenzymes or a change of the intracellular calcium concentration. ${ }^{21}$ Here, we show that LPS and MTP-PE induce a rapid activation of the map kinase isoenzymes ERK-1 and ERK-2. Inhibition of map kinase by PD 98059 completely suppresses TNF- $\alpha$ release after LPS and

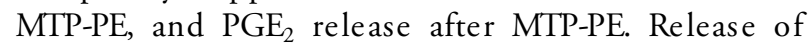
nitric oxide and $\mathrm{PGE}_{2}$ after LPS are partially inhibited by PD 98059 . These data indicate that activation of the map kinase isoenzymes ERK-1 and ERK-2 is an essential step for TNF- $\alpha$ release by LPS and MTP-PE, and for $\mathrm{PGE}_{2}$ formation by MTP-PE. Nitric oxide release, and $\mathrm{PGE}_{2}$ formation by LPS seem only to be partially mediated by map kinase. In addition, we demonstrate here, that the transcription factors NF-kB and AP-1 are activated by LPS. Activation of both transcription factors by LPS is observed already after $30 \mathrm{~min}$, and persists for more than $24 \mathrm{~h} .{ }^{27}$ The activation of NF-kB and AP-1 by MTP-PE is much weaker pronounced, and becomes detectable only after $5 \mathrm{~h}$. Since mRNAs encoding TNF- $\alpha$, iNOS and COX-2 are expressed at much earlier time-points, it is very unlikely that NF- $\mathrm{kB}$ and $\mathrm{AP}-1$ are involved in these actions of MTP-PE. This conclusion is supported by the finding that BAY 11-7072, an inhibitor for NF$\kappa B$, has no effect on MTP-PE-induced responses. BAY 11-7072 completely suppresses the release of TNF- $\alpha$ and nitric oxide by LPS, and inhibits $\mathrm{PGE}_{2}$ release by LPS by $60 \%$ indicating an involvement of NF- $\mathrm{kB}$ in these actions of LPS.

The LPS- but not the MTP-PE-induced relesase of TNF- $\alpha$ is specifically inhibited by $\mathrm{PGE}_{2}$. In contrast, nitric oxide release by LPS and MTP-PE is enhanced by $\mathrm{PGE}_{2} . \mathrm{PGE}_{2}$ has been shown earlier to exert its suppressing effect on TNF- $\alpha$ release by LPS at the transcriptional level. ${ }^{4}$ However, $\mathrm{PGE}_{2}$ does not affect the activation of NF-kB or AP-1 by LPS. ${ }^{27}$ Here we show, that $\mathrm{PGE}_{2}$ inhibits map kinase activation by LPS, but not by MTP-PE. This indicates that the mechanisms of LPS and MTP-PE leading to activation of map kinase are different. 
MTP-PE, but not LPS, induces a cytotoxicity of macrophages against tumor target cells. The MTP-PE induced cytotoxicity is reduced by TNF- $\alpha$ ne utralizing antibodies, indicating that TNF- $\alpha$ is involved in the cytotoxic action. The lack of cytotoxicity after LPS might be due to the transient release of TNF- $\alpha$, in contrast to the sustained accumulation of TNF- $\alpha$ after MTP-PE. These findings are in line with the fact, that MTP-PE, when administered i.v., induces an antitumor reactivity in animal models. ${ }^{16-20}$ Recently, it has been proposed that the cytotoxicity of macrophages against the adenomacarcinoma line MCA26 is mediated by TNF- $\alpha$, and not by nitric oxide. ${ }^{34}$ Our data support these findings, since LPS and MTP-PE induce an identical release of nitric oxide, but differ in their cytotoxic potencies.

Based on the results presented here, we propose the following scheme for the regulatory role of $\mathrm{PGE}_{2}$ in the action mechanisms of LPS and MTP-PE in macrophages (Fig. 8). LPS (Fig. 8A) activates rapidly the map kinase isoenzymes ERK-1 and ERK-2 and the transcription factors NF-kB and AP-1, which results in a synthesis and release of nitric oxide, TNF- $\alpha$ and $\mathrm{PGE}_{2}$. PGE 2 reduces in a negative feedback loop the activation of ERK-1 and ERK-2, nitric oxide release is enhanced, TNF- $\alpha$ formation is suppressed, cytotoxicity against tumor target cells is low. MTP-PE activates rapidly map kinase isoenzymes ERK-1 and ERK-2, but not the transcription factors NF-kB and AP1. Activation of yet unknown transcription factors results in a synthesis and release of nitric oxide, TNF- $\alpha$ and $\mathrm{PGE}_{2}$. $\mathrm{PGE}_{2}$ has no inhibitory effect on the map kinase isoenzymes ERK-1 and ERK-2, TNF- $\alpha$ release is not suppressed, and the macrophages show a high cytotoxicity against tumor target cells. Further ex periments have to be carried out to elucidate in detail the molecular mechanisms of the regulatory function of $\mathrm{PGE}_{2}$. These ex periments include the investigation of other kinases and other transcription factors, ${ }^{35-38}$, which have been demonstrated in other cells to be involved in the action of LPS, and in the formation of TNF- $\alpha$, nitric oxide and eicosanoids.

ACKNOWLEDGEMENTS. This work was supported by grants from the Deutsche Forschungsgemeinschaft (Di 357/7-1/8-1), the Dr Mildred Scheel Stiftung für Krebsforschung (W 35/93/Di 1), and the Ministerium für Wissenschaft und Forschung Baden-Württemberg (II-729.55-5-2/17). We gratefully acknowledge the assistance of Mrs Kathryn Asman in the preparation of the manuscript.

\section{References}

1. Decker K. Biologically active products of stimulated liver macrophages (Kupffer cells). Eur J Biochem 1990; 192:245-61

2. Duyster J, Schwende H, Fitzke E, Hidaka H, Dieter P. Different roles of PKC $-\beta$ and -(in arachidonic acid cascade, superoxide formation and phosphoinositide hydrolysis. Biochem J 1993; 292:203-7

3. Gaillard T, Mülsch A, Kle in H, Decker, K. Regulation by PGE $_{2}$ of cytokineeilicited nitric oxide synthesis in rat liver macrophages. Biol Chem Hoppe-Seyler 1992; 373:897-902

4. Grewe M, Gausling R, Guyfko K, Hoffmann R, Decker K. Regulation of mRNA expression for tumor necrosis factor. J Hepatol 1994; 20:811-18
5. Dieter P, Fitzke E. Formation of diacylglycerol, inositol phosphates, arachidonic acid and its metabolites in macrophages. Eur J Biochem 1993; 218:753-8

6. Busam KJ, Homfeld A, Zaw atzky R, Bauer J,. Ge rok W, Decker, K. Virus-vs endotoxin-induced activation of liver macrophages. Eur J Biochem 1990; 191:577-82

7. Busam, KJ, Schulze-Specking A, Decker K. Endotoxin-refractory liver macrophages secrete tumor necrosis factor-a upon viral infection. Biol Chem Hoppe-Seyler 1991; 372:157-62

8. Lederer E, Adam A, Ciorbaru R, Petit JF, Wietzerbin, J. Cell walls of mycobacteria and related organisms: chemistry and immunstimulant properties. J Mol Cell Biochem 1975; 7:87-92

9. Ellouz F, Adam A, Ciorbaru R, Lederer, E. Minimal structural requirements for adjuvant activity of bacterial peptidoglycan derivatives. Biochem Biophys Res Commun 1974; 59:1317-22

10. Landmann R,. Obrist R,. Denz H. et al. Pharmacokinetics and immunomodulatory effects on monocytes during prolonged therapy with liposomal muramyltripeptide. Biotherapy 1994; 7:1-12

11. Freudenberg MA, Freudenberg N, Galanos G. Time course of cellular distribution of endotoxin in liver, lung and kidney of rats. BrJ Exp Pathol 1982; 63:56-61

12. Freudenberg MA, Galanos G. Metabolism of LPS in vivo. In: Morrison DC, Ryan JL, eds Bacterial Endotoxin Lipopolysaccharides. Vol. 2. Boca Raton, FL: CRC Press, 1992: 275-85.

13. Fogler WE, Wade R, Brundish DE, Fidler IJ. Distribution and fate of free and liposome-encapsulated $\left[{ }^{3} \mathrm{H}\right]$ muramyl dipeptide and $\left[{ }^{3} \mathrm{H}\right]$ muramyl tripeptide phosphatidylethanolamine in mice. J Immunol 1985; 135:1372-9

14. Izbicki JR, Raedler C, Anke A. et al. Beneficial effect of liposomeencapsulated muramyl tripeptide in experimental septicemia in a porcine model. Infect Immun 1991; 59:126-30

15. Ziegler-Heitbrock HWL, Passlick B,. Käferlein E, Coulie PG, Izbicki JR. Protection against lethal pneumococcal septicemia in pigs is associated with decreased levels of interleukin-6 in blood. Infect Immun 1992; 60: $1692-4$

16. Frost H. MTP-PE in liposomes as a biological response modifier in the treatment of cancer: current studies. Biotherapy 1992; 4:199-204

17. Fidler IJ, Kleinermann ES. Clinical application of phospholipid liposomes containing macrophage activators for therapy of cancer metastasis. $A d v$ Drug Del Rev 1994; 13:325-40

18. Thomas K, Nijenhuis AM, Dontje BHJ, Daemen T, Scherphof GL. Antitumor reactivity induced by liposomal MTP-PE in a liver metastasis model of colon cancer in the rat. Clin Exp Metastasis 1995; 13:328-36

19. Killion JJ, Fidler IJ. Therapy of cancer metastasis by tumoricidal activation of tissue macrophages using liposome-encapsulated immunomodulators. Pharmacol Ther 1998; 78:141-54

20. Lazdins JK, Woods-Cook K, Walker M, Alteri, E. The lipophilic muramyl peptide MTP-PE is a potent inhibitor of HIV replication in macrophages. Aids Res Hum Retroviruses 1990; 6:1157-61

21. Dieter P, Ambs P,. Fitzke E, Hidaka H, Hoffmann R, Schwende, H. Comparative studies of cytotoxicity and the release of TNF- $\alpha$, nitric oxide, and prostanoids of liver macrophages treated with lipopolysaccharide and liposome-encapsulated MTP-PE. J Immunol 1995; 155:2595-604

22. Eyhorn S, Schlayer HJ, Henninger HP et al. Rat hepatic sinusoidal cells in monolaye r culture. J Hepatology 1988; 6:23-35

23. Dieter P, Schulze-Specking A, Karck U, Decker K. Prostaglandin release but not superoxide production by dexamethasone in rat Kupffer cells stimulated in vitro depends on $\mathrm{Na}^{+} / \mathrm{H}^{+}$exchange. Eur J Biochem 1987; 170:201-6

24. Flick DA, Gifford GE. Comparism of in vitro cell cytotoxicity assays for tumor necrosis factor. I Im munol Me thods 1984; 68:167-73

25. Buscher D, Hipskind RA, Krautwald S, Reimann T, Baccarini, M. Rasdependent and independent pathways target the mitogen-activated protein kinase network in macrophages. Mol Cell Biol 1995; 15:466-75

26. Ambs P, Baccarini M, Fitzke E, Dieter P. Role of cytosolic phospholipase $\mathrm{A}_{2}$ in arachidonic acid release of rat-liver macrophages: regulation by $\mathrm{Ca}^{2+}$ and phosphorylation. Biochem J 1995; 22:189-95

27. Tran-Thi TA, Decker K, Baeuerle PA. Differential activation of transcription factors NF-kB and AP-1 in rat liver macrophages. Hepatology 1995; 22:613-18

28. Chomzynski P, Sacchi N. Single-step method of RNA isolation by acid guanidinium thiocyanate-phenol-chloroform extraction. Ann Biochem 1987; 162:156-61

29. Dudley DT, Pang L, Decker SJ, Bridges AJ, Saltiel AR. A synthetic inhibitor of the mitogen-activated protein kinase cascade. Proc Natl Acad Sci USA 199; 15:7686-9

30. Pierce JW, Schoenleber R, Jesmok G et al. Novel inhibitors of cytokineinduced $\mathrm{I}(\mathrm{B}$ (phosphorylation and endothelial cell adhesion molecule expression show anti-inflammatory effects in vivo. J Biol Chem 1997; 272:21096-103

31. Dieter P, Hempel U,. Kamionka S. et al. Lipopolysaccharide and liposome-encapsulated muramyl tripeptide. In: Wisse E, Knook DL, De Zanger R, Frazer R, eds Cells of the Hepatic Sinusoid Vol. 7. Leiden: The Kupffer Cell Foundation Leiden, 1999; 257-9 
32. Peter T, Karck U, Decker K. Interdependence of tumor necrosis factor, prostaglandin E2, and protein synthesis in lipopolysaccharide-exposed rat Kupffer cells. Eur J Biochem 1990; 191:583-6

33. Grewe M, Duyster J, Dieter P, Henninger HP, Schulze-Specking A, Decker K. Prostaglandin D2 and E2 synthases in rat Kupffer cells are antagonistically regulated by lipopolysaccharide and phorbol ester. Biol Chem Hoppe-Seyler 1992; 373:655-9

34. Foletta VC, Segal DH, Cohen DR Transcriptional regulation in the immune system: all roads lead to AP-1. J Leucocyte Biol 1998; 63:139-43

35. Hobbie S, Chen LM, Davis, RJ, Galan JE. Involvement of mitogenactivated protein kinase pathways in the nuclear responses and cytokine production by Salmonella typhimurium in cultured intestinal epithelial cells. J Im munol 1997; 159:5550-9

36. Chan ED, Winston BW, Uh SZ, Wynes MW, Rose DM, Rches DW. Evaluation of the role of mitogen-activated protein kinases in the expression of inducible nitric oxide synthase by IFN- $\gamma$ and TNF- $\alpha$ in mouse macrophages. J Im m unol 1999; 162:415-22

37. Faure V, Hecquet C, Courtois Y, Goureau O. Role of interferon regulatory factor- 1 and mitogen-activated protein kinase pathways in the induction of nitric oxide synthase-2 in retinal pigmented epithelial cells. $J$ Biol Chem 1999; 19:4794-800

38. Goppelt-Struebe M, Hahn A, Stroebel M, Reiser COA. Independent regulation of cyclo-oxygenase 2 expression by $42 / 44$ mitogen-activated prote in kinases and $\mathrm{Ca}^{2+} /$ calmodulin-dependent kinase. Biochem J 1999; 339:329-34

\section{Accepted 24 January 2000}




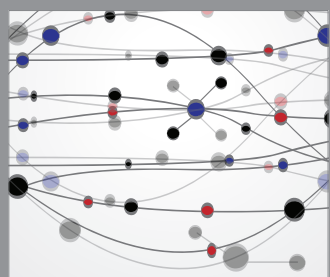

The Scientific World Journal
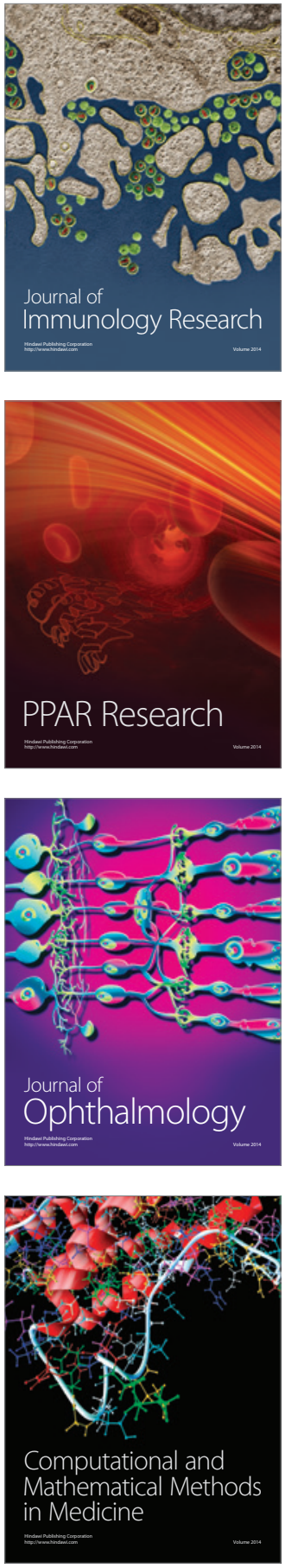

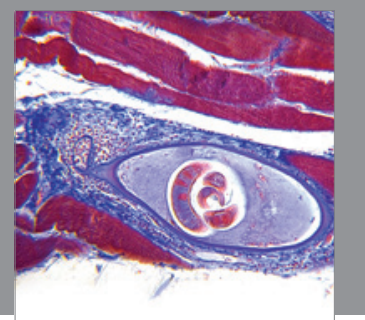

Gastroenterology

Research and Practice
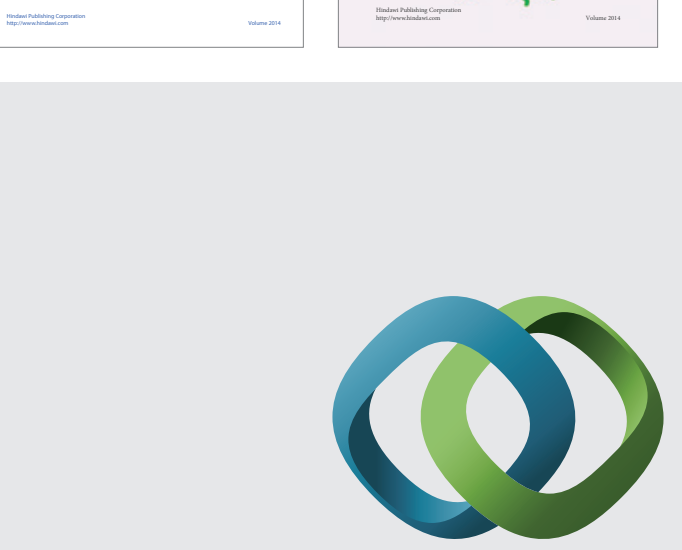

\section{Hindawi}

Submit your manuscripts at

http://www.hindawi.com
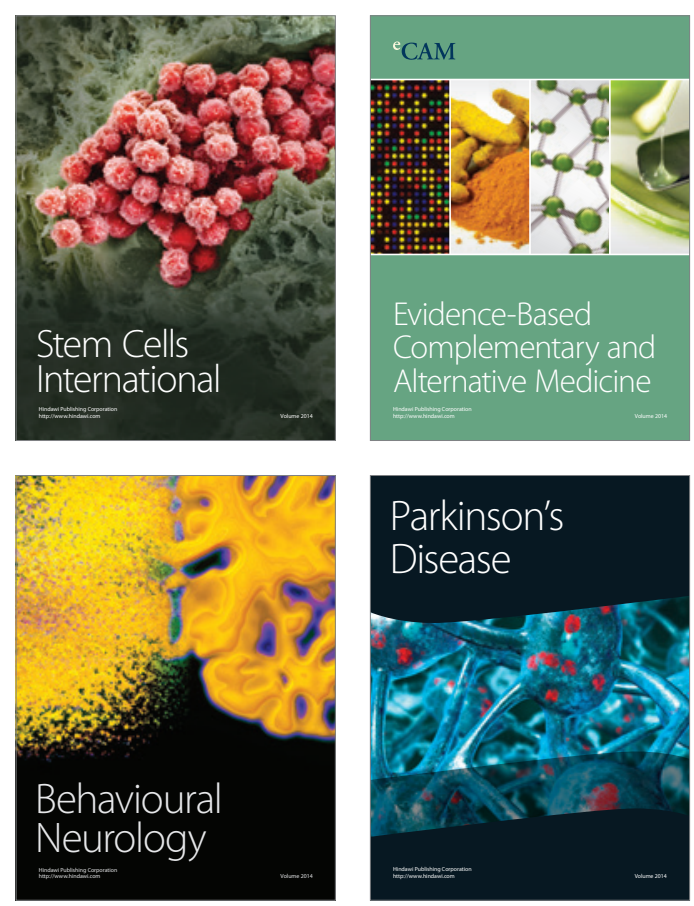

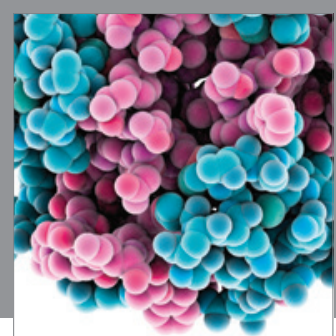

Journal of
Diabetes Research

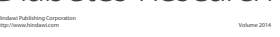

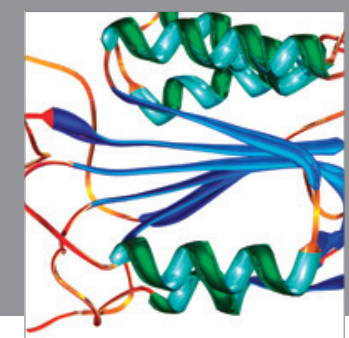

Disease Markers
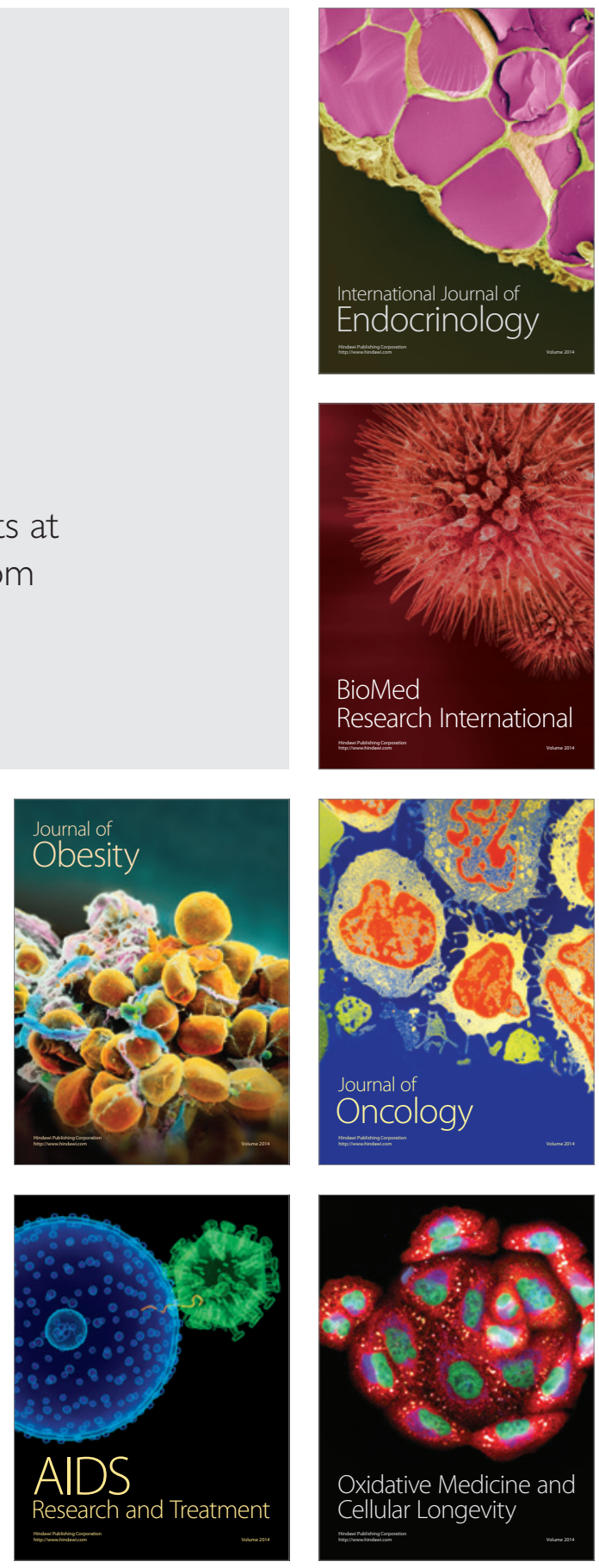